\title{
Discussion on College English Teaching Model in Universities under New Situation
}

\author{
Du Wenjuan \\ School of Foreign Languages, Langfang Teachers University, Langfang, Hebei Province, China \\ 307894582@qq.com
}

\begin{abstract}
In 2007 the "College English Curriculum Requirements" has established the college English teaching model of the student as the center, cultivating the language skills, the students' comprehensive ability and autonomous learning ability. But in 2013 the "Beijing 2014-2016 College Entrance Framework Plan (Draft)" was officially announced. The English teaching in the middle school will be reformed, which will also have a huge impact on college English teaching model. The author put forward the practical teaching model and the elite teaching model, which will provide a feasible scheme for the college English teaching reform.
\end{abstract}

Index Terms - College English, Teaching model, Practical teaching model, Elite teaching model

\section{Introduction}

College English, an integral part of higher learning, is a required basic course for undergraduate students. In 2007 The Higher Education Department of the Ministry of Education promulgated the "College English Curriculum Requirements." In the Requirements it made a significant reform on college English curriculum. It changed the traditional teacher-centered teaching model to the student-centered teaching model. It has established the college English teaching model of the student as the center, cultivating the language skills, the students' comprehensive practical ability and autonomous learning ability as the goal. In recent years, according to the Requirements, many college English teachers and researchers have been trying to research and discuss this teaching model and have made some progress.

In 2013 "Beijing 2014-2016 College Entrance Framework Plan (Draft)" was officially announced. The great reform, especially English reform, has aroused strong concern of the society. In Beijing college entrance examination in 2016, English will be the social examination. The examination will be held two times in one year, and the students can take both of them. The total score will change from 150 points to 100 points. This shows that the State Education Commission will carry on the reform to the current middle school English teaching, and reduce the proportion of English in the university entrance exam, which will exert great influence on college English teaching. Under the new situation, the current college English teaching reform will be imperative. The English teaching staff engaged in college English teaching must consider an important issue of taking what teaching model.

English as a language, its main function is communication. College English teaching should also focus on this characteristic. The author thinks that we can take practical teaching model and elite teaching model.

\section{Practical Teaching Model}

The practical teaching model means that for most students it mainly develops students' listening and speaking abilities, and enhance their ability of communication.

When the freshmen enter the college, they should take the grade examination to evaluate their English level. They can be divided into three levels according to their score. Preparatory level: the preparatory textbook as a starting point. Level one: the first copy of the textbook as a starting point. Level two: the second copy of the textbook as a starting point (also some important contents of the first copy of the textbook). Students in level two will take expansion course in the third or fourth semester. Of course, classification standards shall be formulated by the colleges and universities themselves.

Preparatory level and level one can adopt the practical teaching model, and level two can adopt the elite teaching model to teach students in accordance with their aptitude truly. College English course in the practical teaching model is divided into reading and writing course and viewing, listening and speaking course. Reading and writing course is based on the class, while viewing, listening and speaking course is based on computer network. The time allocation is 1 (reading and writing course) +3 (viewing, listening and speaking course) $+\mathrm{X}$ (autonomous learning) for each week.

The main purpose of reading and writing is to improve students' vocabulary to lay foundation for listening and speaking. It accounts for a small proportion in the course of teaching, and it is mainly for students to learn by themselves, and the teachers are secondary. The teachers are mainly to publish answers and the task of teaching.

Viewing, listening and speaking teaching is the focus of classroom teaching. English, as an international language, has drawn more attention of college and university students, and the ability of listening and speaking is the new requirements to college English teaching put forward by the society. The purpose of learning English is communication, and the premise of communication is understanding what is being said, and then speak based on certain language ability, to achieve the purpose of communication.

This part is the core of the practical teaching model. In the setting of college English curriculum, the proportion of listening and speaking in classes is small, and the teaching model is teacher-centered, that is, the teacher plays the recording - students listen - the teacher questions - students do exercises - students check the answers. Such teaching can 
not stimulate students interest in listening and speaking, but will dampen the enthusiasm of students learning English and make them lack confidence in the training process of listening and speaking. Therefore, the teacher should use the teaching methods suitable for different level students in the teaching practice to strengthen students' listening and speaking training, so as to improve their listening and speaking level. How to improve the students' listening and speaking abilities? It can be done from the following aspects:

1) Using modern multimedia teaching model: multimedia teaching formed by audio-visual media and multimedia computer combines texts, graphics, images, animation, and sound etc. to transfer a lot of information to the learner to fully mobilize students' comprehensive use of visual, auditory senses to achieve the purpose of communication.

2) Designing teaching contents flexibly: rationally using the rich communication materials in the textbooks to mobilize the enthusiasm of students and enable them to participate in teaching activities, changing from passive recipients of knowledge into active learners.

3) Expanding the teaching contents: in the classroom design practice, according to the objective and requirement for teaching and teaching materials, increasing the English audiovisual materials with novel content and lively form, such as "Family Album", "Crazy English", news, video, and English songs etc., to achieve harmony between the language and context, arouse the students' interest and motivation, and cultivate the students' language ability.

4) Carrying out interactive teaching: emphasizing personalized learning, taking the student as the center, and paying attention to communicative interaction between teachers and students, students and students, and interaction between various cognitive activities of students, emphasizing the combination of input and output of learners'.

5) Combining inside and outside classroom teaching: class teaching and autonomous learning after class can effectively consolidate the curricular knowledge and provide adequate opportunity to train students' English listening and speaking abilities.

The new teaching model embodies the practicability, culture and entertainment of English viewing, listening and speaking teaching. Combining listening and speaking in teaching with the aid of modern multimedia teaching means and realizing the audio-visual integration of teaching fully mobilize the enthusiasm of the teachers and students, and establish the subject status of students in the teaching process to develop the teaching towards diversification and active learning.

Autonomous learning is a powerful guarantee for the practical teaching model. The new college English curriculum requires to cultivate students' autonomous learning ability. To find learning strategy suitable for students' own characteristics and different tasks by inspiring, guiding and helping students, and give full play to their learning autonomy, and ultimately to improve their ability of using English and absorb new knowledge independently.
Autonomous learning is the supplement to the first two teachings, and is an indispensable part of English Teaching in universities. Autonomous learning can make full use of the network platform, to review and consolidate the emphases and difficulties in classroom teaching, to learn curriculum development, and to evaluate their own learning outcomes.

Methods of cultivating students' autonomous learning ability is varied, and the following practices are common:

1) To encourage students to help each other, and make progress together: To cultivate students' autonomous learning ability is to let the students rely on teachers as less as possible, and the teachers will not intervene in what the students can do by themselves. In addition to the teachers' appropriate guidance, students should cooperate with each other and teach and learn from each other as much as possible, which not only can increase the students' communication and language practice opportunities, but can enhance their confidence, cultivate the spirit of cooperation, and expand the rate and efficiency of classroom time unit.

2) To consciously give the students some extracurricular task: Asking the students to complete the assignments can cultivate their ability to plan, implement and complete a language task on their own. Letting the students do the learning task in their power independently is a good way of improving the ability of autonomous learning, which not only can stimulate students' desire for knowledge and learning motivation, expand knowledge, and increase the amount of language training, but can make the students collect and process information using learning methods and strategies, and solve practical problems, thus learn to study.

3) To require students to record their own learning experience: The cultivation of students' autonomous learning ability is to help students master effective methods, establish "I can learn" self-confidence, and "I will learn" belief. The students can record their experience of learning process, methods, and feelings through the diary or other recording models, and they can do self-monitoring and self-evaluation, to adjust the learning methods and strategies of the next stage.

4) To let the students to prepare and design language materials for one classroom teaching: Teachers can choose some additional materials for classroom teaching to increase students' language practice time. Materials are the topics that students are interested in. Students are willing to participate. Especially after their prepared materials are adopted, their sense of achievement can be imagined, which will have a farreaching influence on their future study.

The practical teaching model is suitable for the majority of students, and this teaching model will become the main model of teaching in colleges and universities.

\section{Elite Teaching Model}

The elite teaching model refers to elite education model to college students of high starting point based on practical teaching model. In addition to the fluent communication with the people, the students must have the professional ability of reading, writing, and translation. 
In this teaching model, the time allocation is 2 (reading and writing course) +2 (viewing, listening and speaking course) + X (autonomous learning) for each week. Viewing, listening and speaking course and autonomous learning are basically the same as that in practical teaching model, and we will not say it any more here.

Reading, writing and translation teaching is the cornerstone of the elite teaching model. The teaching point is completely different from that of the practical teaching model. It requires students to master a large vocabulary, and to have the abilities of reading, writing, and translation.

Reading, writing and translation teaching method should be reformed, fundamentally it is the change of the teaching idea-change from teaching model of the teacher as the center, simply to impart knowledge and skills, to teaching model of students as he center, not only to teach the general language knowledge and skills but to pay more attention to training abilities of language skills and self-learning. The course instructors will often learn advanced teaching idea and experience at home and abroad, dare to explore, innovate actively, and gradually form the modern English teaching model based on classroom teaching and multimedia computer network platform.

Improving the teaching methods and the efficiency of classroom teaching is an important part of college English reading, writing and translation teaching. In the new teaching model, we can carry out the following innovation of teaching methods and means:

1) Using multimedia courseware to teach college English reading, writing and translation. The teachers collaborate to make multimedia courseware of college English reading, writing and translation. The teachers adjust the courseware contents to make the electronic courseware with personalization according to the students' English level.

2) Changing the teaching method from the traditional "word by word, sentence by sentence" to instructive teaching. In imparting language knowledge, the teachers pay attention to training students' abilities of language skills, reading, writing and translation.
3) Taking student-centered classroom teaching model. The teachers make full use of multimedia technology in education and flexible teaching methods to enhance students' subjective initiative and sense of participation, and organize active and effective classroom teaching to improve students' ability of using language.

It should be stressed that, the new teaching model supported by modern information technology, especially network technology, makes college English teaching change to a personalized, task-driven autonomous learning. The new teaching model embodies the principles of practice, culture and entertainment of English teaching. The new teaching model fully mobilizes the enthusiasm of teachers and students, especially establishes the main position of students in the teaching process. In addition, in the full use of modern information technology, the new teaching model also fully considers and reasonably inherits the good parts of the existing teaching model.

\section{Summary}

Under new situation, the teaching reform of college English is imperative. The coexistence of the practical teaching model and the elite teaching model will become an inevitable trend. This is only a preliminary assumption. Yet the establishment of these two models have to be further improved, differing from man to man, from school to school.

\section{References}

[1] The Higher Education Department of the Ministry of Education, College English Curriculum Requirements, Beijing: Foreign Language Teaching and Research Press, 2007.

[2] P. Benson and P. Volle, Autonomy and Independence in Language Learning, London: Longman, 1997.

[3] L. Shuang, "Practice on level-based college English teaching model under CALL environments," 2012 International Conference on Computer Distributed Control and Intelligent Environmental Monitoring, pp. 501504, 2012.

[4] N. David, The Learner-centered Curriculum: A Study in Second Language Teaching, Shanghai: Shanghai Foreign Language Education Press, 2001.

[5] S. G. Yong, "Consideration on college English teaching model under Information Age," 2010 Second International Conference on Multimedia and Information Technology, vol. 1, pp. 198-201, 2010. 